\title{
ANALISIS SUMBER BELAJAR LKS PENGANTAR AKUNTANSI DENGAN PERNYATAAN STANDAR AKUNTANSI KEUANGAN NOMOR 1 TAHUN 2013
}

\author{
${ }^{1}$ Dini Octoria, ${ }^{2}$ Sudiyanto \\ 1,2 Program Studi Pendidikan Akuntansi, Fakultas Keguruan dan Ilmu Pendidikan, \\ Universitas Sebelas Maret
}

Email: viva_dini_ku@yahoo.com

\begin{abstract}
Abstrak
Penelitian ini bertujuan untuk mengetahui kesesuaian sumber belajar LKS Pengantar Akuntansi dengan Pernyataan Standar Akuntansi Keuangan (PSAK) Nomor 1 Tahun 2013. Penelitian ini menggunakan pendekatan kualitatif dengan desain penelitian kualitatif verifikatif. Penelitian ini dilakukan di salah satu SMK di Surakarta, yang dilaksanakan pada tahun 2016. Sumber data yang digunakan adalah dokumen berupa LKS Pengantar Akuntansi dan Pernyataan Standar Akuntansi Keuangan (PSAK) Nomor 1 Tahun 2013. Teknik pengumpulan data yang digunakan adalah studi dokumentasi dengan melakukan content analysis pada dokumen LKS dan PSAK. Teknik analisis data menggunakan analisis data kualitatif yang terdiri dari tahap reduksi data, penyajian data dan penarikan kesimpulan. Prosedur penelitian ini terdiri dari empat tahapan, yaitu persiapan penelitian; pelaksanaan penelitian; analisis data; penyusunan laporan penelitian. Hasil penelitian menunjukkan bahwa sumber belajar berupa LKS Pengantar Akuntasi yang digunakan peserta didik di salah satu SMK Surakarta belum sesuai dengan PSAK No. 1 Tahun 2013. Terdapat 13 dari total 14 sub indikator pada materi laporan keuangan yang belum sesuai dengan PSAK No. 1 Tahun 2013. Dengan berdasar pada simpulan penelitian, diharapkan agar guru dapat lebih selektif lagi dalam menggunakan sumber belajar, khususnya selektif dalam memilih isi atau content sumber belajar yang sesuai dengan perkembangan ilmu pengetahuan.
\end{abstract}

Kata Kunci: Sumber Belajar, Pengantar Akuntansi, Standar Akuntansi Keuangan

Indonesia sebagai negara dengan jumlah penduduk terbesar di kawasan Asia Tenggara, diharapkan juga dapat menjadi negara dengan tingkat kesejahteraan tertinggi di tingkat ASEAN. Untuk meningkatkan tingkat kesejahteraan tentu saja membutuhkan dukungan dari berbagai bidang seperti pendidikan, kesehatan, ekonomi, stabilitas politik, infrastruktur dan lain sebagainya. Bidang pendidikan merupakan salah satu bidang penting yang memberikan kontribusi positif pada suatu Negara, terlebih dengan berlakunya ASEAN Free Trade Area pada tahun 2015. Dalam rangka mewujudkan Indonesia yang berdaulat, mandiri dan berkepribadian dengan berlandaskan gotong royong, Presiden Joko Widodo telah merumuskan sembilan agenda prioritas atau dikenal dengan Nawa Cita. Agenda prioritas yang terkait dengan bidang pendidikan adalah meningkatkan kualitas hidup manusia dan masyarakat Indonesia, dengan memberikan layanan pendidikan yang berkualitas akan menghasilkan lulusan yang terampil dan siap memasuki dunia kerja

SMK merupakan satuan pendidikan jalur formal pada jenjang pendidikan menengah yang menghasilkan lulusan siap bekerja. Peserta didik SMK tidak hanya mendapatkan teori pengetahuan saja, tetapi juga mewajibkan peserta didik untuk praktik kerja industri. Dengan demikian SMK dapat menghasilkan tenaga kerja terampil sesuai dengan tutuntan dunia usaha dan dunia industri, serta siap bersaing dengan tenaga kerja asing. Dengan mengacu pada Surat Keputusan Direktur Jederal Pendidikan Dasar dan Menengah Kementerian Pendidikan dan Kebudayaan Nomor 4678/D/Kep/MK/2016 tentang Spektrum Pendidikan Menengah Kejuruan, diketahui bahwa penyelenggaraan pendidikan menengah kejuran terdiri dari 9 Bidang Keahlian 
yaitu: (1) Teknologi dan Rekayasa; (2) Energi dan Pertambangan; (3) Teknologi Informasi dan Komunikasi; (4) Kesehatan dan Pekerjaan Sosial; (5) Agribisnis dan Agroteknologi; (6) Kemaritiman; (7) Bisnis dan Manajemen; (8) Pariwisata; dan (9) Seni dan Industri Kreatif. Dari sembilan bidang keahlian tersebut, bidang keahlian bisnis dan manajemen merupakan bidang dengan populasi jumlah sekolah dan peserta didik yang memiliki trend meningkat setiap tahunnya. Bidang Keahlian Bisnis dan Manajemen terdiri dari Program Keahlian Bisnis dan Pemasaran, Manajemen Perkantoran, serta Akuntansi dan Keuangan.

Program Keahlian Akuntansi dan Keuangan merupakan Program Keahlian yang lulusannya sangat dibutuhkan dala dunia kerja, karena tenaga kerja akuntansi dan keuangan selalu dibutuhkan pada setiap instansi pemerintah dan non pemerintah, baik profit maupun non profit. Untuk menghasilkan tenaga kerja akuntansi dan keuangan yang terampil, penyelenggaraan pendidikannya harus mengacu pada Standar Nasional Pendidikan yang termuat dalam Peraturan Pemerintah Republik Indonesia Nomor 13 Tahun 2015 pada pasal 1, menyebutkan, "Standar Nasional Pendidikan adalah kriteria minimal tentang sistem pendidikan di seluruh wilayah Indonesia." Selanjutnya Standar Nasional Pendidika tersebut terdiri dari delapan standar yaitu: (1) Standar Isi; (2) Standar Proses; (3) Standar Kompetensi Lulusan; (4) Standar Pendidik dan Tenaga Kependidikan; (5) Standar Sarana dan Prasarana; (6) Standar Pengelolaan; (8) Standar Pembiayaan; (9) Standar Penilaian Pendidikan.

Keseluruhan lingkup Standar Nasional Pendidikan tersebut saling berkaitan dan mutlak dipenuhi agar dapat menciptakan pendidikan yang berkualitas.

Dari ke delapan standar tersebut, Standar Proses merupakan standar yang melibatkan langsung subjek utama dalam pembelajaran, yaitu peserta didik dan guru. Menurut Peraturan Menteri Pendidikan dan Kebudayaan Republik Indonesia Nomor 22 Tahun 2016 mengemukakan bahwa Standar Proses merupakan kriteria mengenai pelaksanaan pembelajaran pada satuan pendidikan dasar dan menengah untuk mencapai kompetensi lulusan. Terkait dengan pernyataan di atas, pelaksanaan standar proses tidak hanya meliputi kegiatan pada saat berlangsungnya proses pembelajaran akan tetapi mencakup perencanaan proses pembelajaran, pelaksanaan proses pembelajaran, penilaian hasil pembelajaran untuk meningkatkan efisiensi dan efektivitas ketercapaian kompetensi lulusan.

Salah satu cakupan dalam standar proses adalah perencanaan proses pembelajaran. Perencanaan merupakan kegiatan yang dijadikan pedoman guru dalam melakukan proses pembelajaran. Dengan melakukan perencanaan proses pembelajaran diharapkan kegiatan selama pembelajaran akan lebih tertata dan memiliki hasil yang baik pula. Perencanaan proses pembelajaran dirancang dalam bentuk silabus dan rencana pelaksanaan pembelajaran, yang di dalamnya terdapat beberapa unsur salah satunya adalah sumber belajar.

Sumber belajar adalah segala sesuatu yang digunakan sebagai rujukan bahan untuk kegiatan pembelajaran. Jenis sumber belajar telah diatur dalam Peraturan Menteri Pendidikan dan Kebudayaan Republik Indonesia Nomor 22 Tahun 2016 yang dapat berupa buku, media cetak dan elektronik, alam sekitar atau sumber belajar lain yang relevan. Sumber belajar yang baik tentu harus memiliki kesesuaian, baik kesesuaian jumlah sumber belajar yang tersedia dengan karateristik satuan pendidikan, dan juga kesesuaian isi sumber belajar dengan karakteristik satuan pendidikan. Hal ini sejalan dengan kriteria sumber belajar yang tertuang dalam Peraturan Pemerintah Republik Indonesia Nomor 32 Tahun 2013 Pasal 43 Ayat 6 yang menyebutkan bahwa, "Standar sumber belajar dinyatakan dalam rasio jumlah sumber belajar terhadap peserta didik sesuai dengan jenis sumber belajar dan karakteristik satuan pendidikan."

Sumber belajar yang digunakan harus memiliki rasio yang sesuai dengan jumlah peserta didik yang ada. Dalam arti bahwa setiap peserta didik dapat memiliki dan atau mengakses sumber belajar tersebut. Selanjutnya, sumber belajar juga harus memiliki 
kesesuaian dengan karakteristik SMK yang tercermin dalam Standar Kompetensi Lulusan (SKL), yaitu pendidikan menengah yang mempersiapkan peserta didik terutama untuk bekerja dalam bidang tertentu. Terkait dengan SMK Program Keahlian Akuntansi dan Keuangan, sudah seharusnya menggunakan sumber belajar yang isinya memberikan wawasan pengetahuan dan keterampilan yang selaras dengan kebutuhan dunia usaha dan industri.

SMK Negeri 3 Surakarta merupakan salah satu sekolah formal yang terdapat Program Keahlian Akuntansi dan Keuangan. Dalam kegiatan pembelajaran di sekolah, peserta didik menggunakan berbagai macam sumber belajar yang telah disediakan oleh guru maupun pihak sekolah. Salah satu sumber belajar yang digunakan adalah Lembar Kegiatan Peserta didik (LKS). Berdasarkan hasil observasi pra penelitian pada SMK Negeri 3 Surakarta diketahui bahwa sumber belajar LKS yang digunakan pada Kompetensi Keahlian Akuntansi belum memenuhi kriteria sumber belajar yang baik. Hal ini dikarenakan isi LKS yang digunakan tidak sesuai dengan karakteristik satuan pendidikan Program Keahlian Akuntansi dan Keuangan. Ketidaksesuaian karakteristik yang dimaksud dalam hal ini adalah ketidaksesuaian isi LKS dengan peraturan akuntansi terbaru yaitu Pernyataan Standar Akuntansi dan Keuangan (PSAK) Tahun 2013. Hasil observasi menunjukkan bahwa LKS yang digunakan pihak sekolah tidak mengikuti perkembangan PSAK terbaru. Sebagai contoh ketidaksesuaian isi LKS dengan PSAK Tahun 2013 adalah masih adanya penggunaan istilah maupun nama akun yang sebenarnya sudah tidak digunakan lagi atau dihapus dalam PSAK terbaru. Penggunan istilah dan nama akun yang sudah tidak sesuai, tentu akan menyulitkan lulusan SMK tersebut ketika akan memasuki dunia kerja karena perbedaan konsep antara yang dipelajari saat sekolah dengan kebutuhan dunia kerja dunia industri.

Berdasarkan pada uraian sebelumnya, maka permasalahan yang diajukan adalah, "Apakah sumber belajar LKS Pengantar Akuntansi yang digunakan di SMK Negeri 3 Surakarta sudah sesuai dengan PSAK Tahun 2013?" Selanjutnya, tujuan dari penelitan ini adalah untuk mengetahui sesuai atau tidaknya sumber belajar LKS Pengantar Akuntansi yang digunakan di SMK Negeri 3 Surakarta dengan PSAK Tahun 2013. Dengan mengetahui sesuai atau tidaknya, diharapkan penelitian ini dapat memberikan wawasan baru bagi guru SMK Negeri 3 Surakarta dalam memilih dan menggunakan sumber belajar yang sesuai dengan kebutuhan dunia kerja dan dunia industri.

\section{KAJIAN PUSTAKA}

Pembelajaran pada jalur pendidikan formal merupakan proses interaksi antara peserta didik dengan guru dan sumber belajar lainnya dalam suatu lingkungan belajar. Secara luas definisi pembelajaran dikemukakan oleh Mayer dalam Ambrose et al (2010: 29) yaitu, "Learning as a process that leads to change, which occurs as a result of experience and increases the potential of improved performance and future learning" Pembelajaran diartikan sebagai proses menuju perubahan yang terjadi sebagai akibat dari pengalaman dan peningkatan potensi untuk peningkatan kinerja dan pembelajaran di masa yang akan datang. Inti dari pembelajaran adalah proses, dan perubahan perilaku. Proses adalah interaksi antara peserta didik dengan sumber belajar, perubahan perilaku adalah output yang dihasilkan dari pengalaman belajar.

Sumber belajar atau dikenal dengan learning resources memiliki peranan yang cukup penting dalam pembelajaran. Bentuk dari sumber belajar tidak hanya terbatas pada buku dan media cetak serta elektronik saja, tetapi juga berupa living laboratory dan tentu saja guru yang dapat digunakan oleh peserta didik dalam memberikan informasi berupa ilmu pengetahuan 
yang dapat menghasilkan perubahan perilaku dalam pengalaman belajar. Association for Education and Communication Technology (ACET) mendefinisikan sember belajar sebagai berikut, "Learning resources (for educational technology) all of the resources (data, people, and things) which may be used by the leaner in or combination, usually in an formal manner to facilitate learning: they include messages, people, materials, devices, techniques, and settings (Musfiqon: 129)." Pengertian tersebut menegaskan bahwa sumber belajar adalah semua sumber baik berupa data, orang dan wujud tertentu yang dapat digunakan oleh peserta didik dalam belajar, baik secara terpisah maupun secara terkombinasi sehingga mempermudah peserta didik dalam mencapai tujuan belajar atau mencapai kompetensi tertentu.

Sejalan dengan itu, Peraturan Menteri Pendidikan dan Kebudayaan Republik Indonesia Nomor 22 Tahun 2016 tentang Standar Proses Pendidikan Dasar dan Menengah telah menjelaskan bahwa sumber belajar yang digunakan dalam kegiatan pembelajaran dapat berupa buku, media cetak dan elektronik, alam sekitar atau sumber lain yang relevan. Mencermati peraturan di atas, sumber belajar tidak hanya berupa media cetak dan elektronik namun dapat berupa sumber lain yang relevan misalnya buku ajar, maket, model, modul, Lembar Kerja Peserta didik (LKS), dan lain sebagainya. Selanjutnya Prastowo (2013:37) memberikan perluasan mengenai bentuk-bentuk sumber belajar dapat berupa buku, LKS, majalah, brosur, poster, ensiklopedia, film, model, transparansi, studio, wawancara, permainan. Dari sekian banyak sumber belajar, selama ini LKS merupakan sumber belajar yang paling praktis, mudah dan paling banyak digunakan dalam kegiatan pembelajaran. LKS merupakan materi ajar yang sudah dikemas sedemikian rupa dengan pola ringkasan materi yang dilengkapi dengan latihan soal, sehingga peserta didik diharapkan dapat mempelajari materi tersebut secara mandiri.

Terkait dengan SMK sebagai satuan pendidikan yang berorientasi untuk menghasilkan lulusan yang terampil dan siap bersaing dalam dunia usaha dunia industri, dalam pembelajarannya juga harus didukung dengan sumber belajar yang sesuai dengan karakteristik peserta didik dan mata pelajaran. Selain pembelajaran yang dilakukan di ruang praktik, beberapa SMK juga masih menggunakan sumber belajar berupa LKS untuk membantu peserta didik dalam pembelajarannya. Oleh karena itu, bentuk sumber belajar yang difokuskan dalam penelitian ini adalah LKS mata pelajaran Pengantar Akuntansi pada SMK Program Keahlian Akuntansi dan Keuangan. Pemilihan sumber belajar LKS mempertimbangkan bahwa materi dalam LKS harus up to date dan sesuai dengan tuntutan perkembangan jaman, agar dapat menghasilkan lulusan SMK yang terampil dan siap serta dapat memenangkan persaingan kompetisi kerja.

Akuntansi berasal dari kata to account yang diartikan sebagai memperhitungkan atau melakukan pertanggungjawaban dari pengelola perusahaan kepada pemilik perusahaan mengenai jalannya kegiatan perusahaan. Horngren, Harrison, Bamber (2004: 4) menyatakan "Accounting is the information systems that measures business activity, process the information into reports and communicates the results to decission markers". Pendapat tersebut mendefinisikan akuntansi sebagai suatu sistem yang mengukur aktivitas-aktivitas bisnis, memproses informasi tersebut ke dalam bentuk laporan-laporan dan mengkomunikasikannya kepada para pengambil keputusan. Sejalan dengan itu Kimmel, Weygandt, Kieso mendefiniskan sebagai berikut, (2009: 6) "Accounting is the information system that indetifies, records, and communicates the economics events of an organization to interested users." Akuntansi merupakan suatu sistem informasi yang terdiri dari tiga kegiatan utama yaitu identifikasi, pencatatan, dan pengkomunikasian kejadian ekonomi suatu organisasi kepada pihak yang membutuhkan. Inti dari akuntansi adalah informasi keuangan yang dihasilkannya, untuk itu proses identifikasi dan pencatatan harus dikerjakan secara benar dan sesuai dengan aturan serta konsep akuntansi agar menghasilkan informasi keuangan yang valid. 
SMK Program Keahlian Akuntansi dan keuangan membekali peserta didik dengan keahlian dan keterampilan akuntansi sehingga peserta didik dapat bekerja sesuai dengan keahliannya ketika telah lulus dari sekolah. Akuntansi di SMK merupakan mata pelajaran yang masih menjadi bagian dari mata pelajaran produktif. Mata pelajaran ini mencakup prinsip dan praktik akuntansi, proses akuntansi, siklus akuntansi yaitu mulai dari proses pencatatan sampai dengan laporan keuangan pada suatu unit usaha/perusahaan. Permendikbud Nomor 70 Tahun 2013 tentang Kerangka Dasar dan Struktur Kurikulum SMK/MAK menguraikan Kompetensi Dasar pada mata pelajaran Pengantar Akuntansi untuk kelas XI, peserta didik dituntut menguasai Kompetensi Dasar berikut ini:

1. Menjelaskan pengertian, tujuan dan peran akuntansi

2. Menjelaskan pihak-pihak yang membutuhkan informasi akuntansi

3. Menjelaskan profesi dan jabatan dalam akuntansi

4. Menjelaskan bidang-bidang spesialisasi akuntansi

5. Menjelaskan jenis dan bentuk badan usaha

6. Menjelaskan prinsip-prinsip dan konsep dasar akutansi.

7. Menjelaskan tahapan proses pencatatan

8. Menjelaskan transaksi bisnis perusahaan

9. Menerapkan persamaan dasar akuntansi

10. Menjelaskan pengertian, jenis, fungsi, dan pengodean akun serta hubungan akun dengan persamaan dasar akuntansi

11. Menjelaskan pencatatan transaksi dalam akun

Berdasarkan uraian di atas, mata pelajaran Pengantar Akuntansi di SMK adalah pengetahuan dan keterampilan dasar akuntansi yang meliputi prinsip, proses dan siklus akuntansi. Untuk selanjutnya, penelitian ini tidak membahas keseluruhan materi yang diberikan, namun terfokus pada materi siklus akuntansi yaitu laporan keuangan. Pemilihan materi tersebut didasari karena laporan keuangan merupakan output dari siklus akuntansi, yang dibutuhkan oleh pengguna informasi keuangan untuk pengambilan keputusan.

Implementasi akuntansi di Indonesia mengacu pada Standar Akuntansi Keuangan (SAK), yang terdiri dari dua bagian yaitu Pernyataan Standar Akuntansi Keuangan (PSAK) dan Interpretasi Standar Akuntansi keuangan (ISAK) yang diterbitkan oleh Dewan Standar Ikatan Akuntan Indonesia dan Dewan Standar Syariah Ikatan Akuntan Indonesia. Keseluruhan aturan tersebut yang selanjutnya dijadikan acuan dalam mebelajarkan konsep akuntansi pada mata pelajaran Pengantar Akuntansi di SMK. Terkait dengan materi laporan keuangan yang difokuskan pada penelitian ini, maka aturan yang digunakan adalah PSAK No. 1 Tahun 2013 tentang Penyajian Laporan Keuangan.

PSAK No. 1 merupakan salah satu bab dalam PSAK yang mengatur tentang penyajian laporan keuangan. Pokok bahasan dalam PSAK No. 1 Tahun 2013 meliputi : a) Pendahuluan; b) Laporan Keuangan; c) Stuktur dan Isi. Seiring perkembangan waktu dan pergeseran kebutuhan penyajian laporan keuangan yang terjadi dalam entitas maupun masyarakat, terdapat beberapa perubahan yang cukup signifikan antara PSAK No. 1. (2013) dengan PSAK No.1 (2009), yaitu:

Tabel 1. Perbedaan PSAK No.1 (2013) dengan PSAK No.1 (2009)

\begin{tabular}{|c|c|c|}
\hline Perihal & ED PSAK 1 (2013) & PSAK 1 (2009) \\
\hline Judul laporan & Laporan Laba Rugi Komprehensif & $\begin{array}{l}\text { Laporan Laba Rugi dan Penghasilan } \\
\text { Komprehensif Lain }\end{array}$ \\
\hline Definisi & $\begin{array}{l}\text { Tidak memberi definisi mengenai: } \\
\text { 1. Laba rugi } \\
\text { 2. Pemlilik } \\
\text { 3. Penyesuaian Reklasifikasi } \\
\text { 4. Total Laba Rugi Komprehensif }\end{array}$ & $\begin{array}{l}\text { Memberikan definisi mengenai: } \\
\text { 1. Laba rugi } \\
\text { 2. Pemilik } \\
\text { 3. Penyesuaian Reklasifikasi } \\
\text { 4. Total Laba Rugi Komprehensif }\end{array}$ \\
\hline $\begin{array}{l}\text { Komponen } \\
\text { laporan } \\
\text { keuangan }\end{array}$ & $\begin{array}{l}\text { Komponen Laporan Keuangan } \\
\text { Lengkap: } \\
\text { 1. Laporan posisi keuangan } \\
\text { 2. Lavoran laba nugi dan nenghasila }\end{array}$ & $\begin{array}{l}\text { Komponen Laporan Keuangan } \\
\text { Lengkap: } \\
\text { 1. Laporan posisi keuangan } \\
\text { 2. Laporan laba nugi komprehensif }\end{array}$ \\
\hline
\end{tabular}


Uraian mengenai perubahan PSAK No. 1 (2013) dengan PSAK No. 1 (2009) tersebut menunjukkan bahwa konsep akuntansi terus mengalami pembaharuan seiring dengan perkembangan kemajuan ilmu pengetahuan dan teknologi. LKS Pengantar Akuntansi sebagai salah satu sumber belajar juga harus mengikuti perubahan tersebut agar menghasilkan lulusan SMK yang bisa dan hebat, yaitu lulusan SMK yang siap kerja, santu, mandir, dan kreatif. Dengan mengacu pada uraian sebelumnya, untuk mengetahui kesesuaian LKS Pengantar Akuntansi dengan PSAK No. 1 Tahun 2013 penelitian ini menggunakan indikator sebagai berikut:

Tabel 2. Indikator Penelitian

\begin{tabular}{|c|l|ll|}
\hline No. & \multicolumn{1}{|c|}{ Indikator } & \multicolumn{1}{c|}{ Sub Indikator } \\
\hline 1. & Konsep dasar laporan keuangan & a. & Pengertian laporan keuangan \\
& & b. & Tujuan laporan keuangan \\
& & c. & Karakteristik laporan keuangan \\
& & d. & Pengguna laporan keuangan \\
& & e. & Komponen laporan keuangan \\
\hline 2. & Laporan posisi keuangan & a. & Pengertian laporan posisi keuangan \\
& & b. & Unsur laporan posisi keuangan \\
& & c. & Struktur laporan posisi keuangan \\
\hline 3. & Laporan laba rugi dan & a. & Pengertian laporan laba rugi dan \\
& penghasilan komperhensif lain & penghasilan komperhensif lain \\
& & b. & Unsur laporan laba rugi dan \\
& & cenghasilan komperhensif lain \\
& & c. & Struktur laporan laba rugi dan \\
& & & penghasilan komperhensif lain \\
\hline
\end{tabular}




\section{METODOLOGI}

Penelitian ini dilakukan di salah satu SMK di Surakarta, yang dilaksanakan pada tahun 2016. Selanjutnya penelitian ini menggunakan pendekatan penelitian kualitatif dengan desain penelitian kualitatif verifikatif. Sumber data yang digunakan adalah dokumen yang berupa LKS pengantar akuntansi dan Pernyataan Standar Akuntansi Keuangan (PSAK) Tahun 2013. Teknik pengumpulan data yang digunakan adalah studi dokumnetasi, dengan melakukan content analysis pada dokumen LKS dan PSAK. Teknik analisis data menggunakan analisis data kualitatif yang terdiri dari tahap reduksi data, penyajian data dan penarikan kesimpulan/verifikasi. Prosedur penelitian adalah sebagai berikut: (1) persiapan penelitian; (2) pelaksanaan penelitian; (3) analisis data; dan (4) penyusunan laporan penelitian.

\section{HASIL DAN PEMBAHASAN}

Berdasarkan pelaksanaan penelitian yang telah dilakukan terkait analisis sumber belajar LKS Pengantar Akuntansi yang digunakan dalam proses pembelajaran, diperoleh data berupa isian tabel verifikasi LKS Pengantar Akuntansi yang digunakan dengan PSAK Nomor 1 Tahun 2013. Hasil penelitian menunjukkan bahwa dari 14 sub indikator terdapat 13 sub indikator materi LKS Pengantar Akuntansi yang belum memiliki kesesuaian dengan PSAK Nomor 1 Tahun 2013, atau secara persentase terdapat 93\% ketidaksesuaian untuk materi laporan keuangan yang terdapat pada LKS Pengatar Akuntansi dengan PSAK Nomor 1 Tahun 2013.

Sub indikator yang pertama yang tidak sesuai adalah yaitu tujuan laporan keuangan, LKS Pengantar Akuntansi hanya menekankan pada informasi yang menyangkut posisi keuangan, kinerja keuangan, dan perubahan posisi keuangan, serta ditujukan untuk kebutuhan para pihak pemakai informasi. Hal ini berbeda dengan PSAK No. 1 Tahun 2013 yang menyampaikan tujuan laporan keuangan tidak terbatas pada komponen laporan keuangan semata, tetapi juga menyebutkan tujuan untuk memberikan informasi arus kas entitas. Selain itu PSAK No. 1 Tahun 2013 juga menyebutkan laporan keuangan digunakan sebagai alat pertanggungjawaban manajemen. Jika hal ini yang digunakan sebagai sumber belajar peserta didik dalam memahami tujuan laporan keuangan, maka pemahaman peserta didik menjadi sempit, terbatas, dan tidak sesuai dengan PSAK No. 1 Tahun 2013 yang dijadikan acuan implementasi akuntansi di Indonesia.

Sub indikator kedua yang tidak sesuai dengan PSAK No. 1 Tahun 2013 adalah karakteristik laporan keuangan. LKS Pengantar Akuntansi hanya menguraikan karakteristik secara sederhana yaitu relevan, handal, keterbandingan, dan konsistensi. Berbeda dengan PSAK No. 1 Tahun 2013 yang menguraikan secara rinci menjadi 6 karakteristik sebagai berikut: 
1. Dapat dipahami

2. Relevan

3. Keandalan

4. Dapat dibandingkan

5. Kendala informasi yang relevan dan andal

6. Penyajian wajar

Perbedaan pada sub indikator kedua juga terdapat dalam menguraikan konsep karakteristik keandalan. LKS Pengantar Akuntansi hanya meliputi pada dapat diperiksa, panyajian jujur dan netral sedangkan PSAK No. 1 Tahun 2013 meliputi substansi mengungguli bentuk, petimbangan sehat, dan kelengkapan. Ketidaksesuaian sub indikator karakteristik kedua ini jika diajarkan pada peserta didik tentu saja sangat menggangu pemahaman dasar akuntansi peserta didik, karena sejak awal mereka sudah diberikan pemahaman terbatas mengenai karakteristik laporan keuangan. Kerugian ini bisa diminimalisir jika peserta didik memiliki inisiatif sendiri untuk mengeksplor pengetahuannya melalui sumber lain khususnya dengan membaca buku asing, tetapi dalam kenyataanya peserta didik tidak memiliki inisiatif tersebut.

Selanjutnya, sub indikator ketiga yang tidak memiliki kesesuaian adalah pengguna laporan keuangan. LKS Pengantar Akuntansi juga masih terbatas dalam menguraikannya, perbedaannya adalah pada pemasok sebagai pengguna laporan keuangan. Pemasok secara jelas sebagai pihak pengguna laporan keuangan, karena dengan mengetahui laporan keuangan pemasok dapat mengukur tingkat pengembalian hutang dan volume penjualan yang dilakukan oleh perusahaan yang menghasilkan laporan keuangan.

Sub indikator keempat adalah komponen laporan keuangan. PSAK No. 1 Tahun 2013 secara eksplisit menyebutkan komponen laporan keuangan sebagai berikut:

1. Laporan posisi keuangan pada akhir periode

2. Laporan laba rugi dan penghasilan komprehensif lain selama periode

3. Laporan perubahan ekuitas selama periode

4. Laporan arus kas selama periode

5. Catatan atas laporan keuangan

6. Laporan posisi keuangan pada awal periode sebelumnya ketika entitas menerapkan suatu kebijakan akuntansi secara retrospektif atau membuat penyajian kembali pos-pos laporan keuangan, atau ketika entitas mengklasifikasi pos-pos dalam laporan keuangannya.

Keenam komponen laporan keuangan tersebut tidak seluruhnya dipelajari bagi peserta didik SMK, hanya tiga komponen saja yang dipelajari yaitu komponen satu sampai dengan tiga. Perbedaan mendasar terletak pada penggunaan istilah, yaitu laporan laba rugi menjadi laporan laba rugi dan penghasilan komprehensif lain, serta laporan perubahan modal menjadi laporan perubahan ekuitas, dan neraca menjadi laporan posisi keuangan. Jika peserta didik tetap menggunakan istilah yang terdapat pada LKS, maka ketika terjun ke masyarakat akan menggunakan istilah komponen akuntansi yang out off date. Dalam PSAK No. 1 Tahun 2013 istilah laba rugi bermakna sempit yaitu total penghasilan dikurangi dengan beban, sedangkan untuk mengukur kinerja keuangan suatu entitas perlu melibatkan penghasilan komprehensif lain yang diperoleh dari selisih penghasilan dan beban di luar kegiatan perasional entitas tersebut.

Selanjutnya PSAK No. 1 Tahun 2013 juga menggunakan istilah ekuitas dalam mendeskripsikan modal, berbeda dengan LKS Pengantar Akuntansi yang menggunakan istilah modal. Modal terbatas hanya pada modal pemilik, sedangkan untuk perusahaan yang berbentuk perseroan terbatas digunakan istilah ekuitas yang terdiri dari saham dan laba ditahan. Perbedaan istilah juga terdapat pada penggunaan istilah neraca pada LKS Pengantar Akuntansi. PSAK No. 1 Tahun 2013 tidak menggunakan istilah neraca, melainkan laporan posisi keuangan. 
Penggunaan istilah laporan posisi keuangan dirasakan tepat karena isi dari neraca adalah menggambarkan posisi keuangan suatu entitas yang berupa aset, liabilitis dan ekuitas.

Selain perbedaan pada penggunaan istilah, perbedaan juga terdapat pada penggunaan keterangan waktu dalam komponen laporan keuangan. Sebagai contoh untuk laporan posisi keuangan dinyatakan pada akhir periode, karena memang berisikan posisi akun-akun pada akhir periode tertentu. Untuk laporan laba rugi dan penghasilan komprehensif lain, dinyatakan dengan keterangan waktu selama periode tertentu. Hal ini tepat karena kinerja keuangan entitas dinyatakan pada kurun waktu periode tertentu. Walaupun keterangan waktu dianggap tidak begitu penting, sesungguhnya keterangan waktu ini yang menandakan waktu dan cakupan dari laporan keuangan yang dihasilkan oleh suatu entitas.

Sub indikator kelima yang belum sesuai adalah pengertian dari laporan posisi keuangan. LKS Pengantar Akuntansi hanya mendefinisikan sebagai suatu daftar aset, kewajiban, dan ekuitas pada saat tertentu untuk menyajikan/menimbang posisi keuangan. Hal ini tentu saja menyalahi konsep laporan posisi keuangan, karena waktu penyusunannya adalah pada akhir periode tertentu, bukan pada saat tertentu. Selama ini dalam menyusun laporan posisi keuangan, peserta didik hanya merekam dan mengimplementasikan pengetahuan berdasarkan apa yang tertulis dalam LKS Pengantar Akuntansi. Jika pemahaman tersebut yang melekat pada peserta didik, tentu saja akan memberikan konsep pemahaman yang salah.

Selanjutnya sub indikator keenam adalah unsur dari laporan posisi keuangan. PSAK No. 1 Tahun 2013 menguraikan unsur tersebut secara spesifik dengan menggolongkan aset dan liabilitas ke dalam beberapa golongan, sedangkan LKS Pengantar Akuntansi hanya menguraikan secara sederhana. Walaupun untuk peserta didik SMK ruang lingkup kegiatan entitas masih sederhana, tetapi dirasakan perlu mengenalkan peserta didik dalam menggolongkan suatu akun yang umumnya digunakan suatu entitas.

Sub indikator ketujuh adalah struktur laporan posisi keuangan. Dengan mengacu pada lampiran 2 dan 3, dapat diketahui bahwa contoh laporan posisi keuangan yang terdapat dalam PSAK No. 1 Tahun 2013 jauh lebih spesifik dan sesuai dengan unsur dari laporan tersebut. Laporan posisi keuangan bukan hanya untuk menampilkan keseimbangan saldo dari total aset dan total liabilitis ditambah ekuitas, tetapi juga untuk menyajikan saldo dan nama akun agar sesuai dengan struktur yang terdapat dalam PSAK No. 1 Tahun 2013, terutama dalam penyajian aset lancar dan aset tidak lancar. Selama ini peserta didik SMK dalam menyusun laporan posisi keuangan hanya mencontoh format yang sudah ada pada LKS Pengantar Akuntansi saja, tanpa merasionalkan apakah format tersebut sudah seusai dengan PSAK No. 1 Tahun 2013. Dirasakan perlu untuk memberikan pemahaman mengenai struktur laporan posisi keuangan, agar apa yang dipelajari peserta didik SMK dapat diaplikasikan ketika mereka bekerja pada dunia usaha.

Sub indikator yang kedelapan adalah pengertian laporan laba rugi dan penghasilan komprehensif lain. Perbedaan dasar yang terjadi dalam sub indikator ini adalah penggunaan istilah kinerja dalam PSAK No. 1 Tahun 2013. Kinerja bukan diartikan sebagai pendapatan dikurangi dengan beban, tetapi diartikan sebagai finance performance yang diperoleh bukan hanya dari perhitungan laba rugi tetapi juga memperhitungkan penghasilan komprehensif lain. Selama ini peserta didik pada bangku SMK memaknai laporan laba rugi hanya berisikan total penghasilan dikurangi dengan beban, jika pemahaman tersebut yang melekat maka peserta didik SMK akan mengimplementasikan pemahaman yang salah dalam dunia kerja.

Selanjutnya adalah sub indikator yang kesembilan unsur laporan laba rugi dan penghasilan komprehensif lain. PSAK No. 1 Tahun 2013 tidak membedakan unsur untuk perusahaan jasa dan dagang, karena menguraikan unsur tersebut secara umum namun dapat diterapkan untuk perusahaan jasa dan dagang. Selain itu PSAK No. 1 Tahun 2013 juga menguraikan penggolongan biaya dan beban secara spesifik. Dengan demikian informasi yang 
dihasilkan akan lebih informatif.

Sub indikator yang kesepuluh adalah struktur laporan laba rugi dan penghasilan komprehensif lain. Sejalan dengan unsur yang telah dikemukakan sebelumnya, struktur laporan laba rugi dan penghasilan komprehensif lain menurut PSAK No. 1 Tahun 2013 disajikan secara lebih spesifik. Hal ini dapat dilihat dari penggolongan pada komponen penghasilan komprehensif lain, yang menguraikan pos-pos yang memberikan dampak terhadap kinerja keuangan suatu entitas, di luar kegiatan operasional entitas tersebut. Selama ini peserta didik di SMK pengetahuan struktur laporan laba rugi dan penghasilan komprehensif lain hanya terbatas pada mennghitung total pendapatan dan beban saja. Pengetahuan tersebut dirasakan tidak sesuai dengan tuntutan dunia kerja, karena entitas yang ada mengacu pada PSAK No. 1 Tahun 2013.

Selanjutnya sub indikator kesebelas yang belum memiliki kesesuaian dengan PSAK No. 1 Tahun 2013 adalah pengertian laporan perubahan ekuitas. Letak perbedaan yang mendasar adalah pada penyajian keterangan waktu laporan tersebut. LKS Pengantar Akuntansi menyajikan keterangan waktu dengan menyebutkan pada suatu periode tertentu. Hal ini tentu saja tidak sesuai dengan konsep laporan perubahan ekuitas, yang disusun selama periode berjalan. Artinya adalah laporan tersebut menyajikan kronologis perubahan ekuitas selama periode tertentu, bukan pada akhir periode.

Sub indikator keduabelas yang belum memiliki kesesuaian adalah unsur dari laporan perubahan ekuitas. PSAK No. 1 Tahun 2013 menyajikan unsur secara spesifik, yang memuat informasi sebagai berikut:

1. Total penghasilan komprehensif selama periode berjalan.

2. Setiap komponen ekuitas.

3. Rekonsiliasi antara jumlah yang tercatat pada awal dan akhir periode.

Untuk LKS Pengantar Akuntansi hanya menyajikan informasi modal awal, laba atau rugi, dan prive. Hal ini tentu saja akan berbeda jika peserta didik sudah terjun dalam dunia usaha, karena pada kenyataannya akan ada informasi lain seperti rekonsiliasi, pembagian deviden, dan lain sebagainya.

Sub indikator terakhir atau yang ketigabelas yang belum memiliki kesesuaian adalah struktur laporan perubahan ekuitas. Sesuai dengan yang telah dikemukakan pada struktur laporan perubahan ekuitas, untuk unsur laporan ini PSAK No. 1 Tahun 2013 juga menyajikan informasi yang lebih rinci dibandingkan informasi yang disajikan pada LKS Pengantar Akuntansi. Dengan informasi yang lebih rinci, maka laporan yang dihasilkan pun akan lebih informatif bagi para penggunanya.

\section{SIMPULAN}

Berdasarkan hasil dan pembahasan yang telah diuraikan, simpulan dari penelitian ini adalah sumber belajar berupa LKS Pengantar Akuntasi yang digunakan peserta didik di salah satu SMK Surakarta belum sesuai dengan PSAK No. 1 Tahun 2013. Terdapat 13 dari total 14 sub indikator pada mater laporan keuangan yang belum sesuai dengan PSAK No. 1 Tahun 2013. Dengan mengacu pada simpulan penelitian, saran yang diajukan dalam penelitian ini ditujukan kepada guru, pihak sekolah yang dalam hal ini adalah sekolah, dan Pemerintah yang dalah hal ini adalah Dinas Pendidikan Kota Surakarta serta Pusat Pengembangan Pendidik dan Pemberdayaan Pendidik dan Tenaga Kependidikan Bisnis dan Pariwisata (PPPPTK Bispar). Saran untuk guru agar dapat lebih selektif lagi dalam menggunakan sumber belajar, khususnya selektif dalam memilih isi atau content sumber belajar yang sesuai dengan perkembangan ilmu pengetahuan. Saran untuk pihak sekolah diharapkan dapat memotivasi dan memfasilitasi guru dalam kegiatan perancangan sumber belajar inovatif, sehingga guru dapat terlibat langsung dalam penyusunan sumber belajar dan dapat memperbaharui ilmu pengetahuan sesuai dengan 
tuntutan dunia usaha dunia industri. Saran untuk Pemerintah diharapkan dapat menyelenggarakan kegiatan workshop penyusunan sumber belajar.

\section{REFERENSI}

Ambrose, Susan A. Bridges, Michael W. DiPietro, Michele. Lovett, Marsha C. Norman, Marie K. (2010). How Learning Works 7 Research-Based Principles for Smart Teaching. San Francisco: Jossey-Bass, A Willey Imprint

Dewan Standar Akuntansi Keuangan - Ikatan Akuntan Indonesia. (2013). Pernyataan Standar Akuntansi Keuangan No. 1 Tahun 2013. Jakarta: IAI

Horngren, Charles T, Walter T. Harisson. \& Linda Smith Bamber. 2004. Accounting. Upper Saddle River: Pearson

Kimmel, Paul D. Weygandt, Jerry J. Kieso, Donald E. (2009). Financia Accounting. New Jersey: John Willey \& Sons Inc.

Musfiqon, HM. (2012). Pengembangan Media dan Sumber Pembelajaran. Yogyakarta: Prestasi Pustaka Publisher.

Prastowo, Andi. (2013). Panduan Kreatif Membuat Bahan Ajar Inovatif. Yogyakarta: DIVA Press.

Republik Indonesia. (2013). Peraturan Menteri Pendidikan dan Kebudayaan Nomor 70 Tahun 2013 tentang Kerangka Dasar dan Standar kurikulum SMK/MAK. Berita Negara Republik Indonesia Tahun 2016. Jakarta.

Republik Indonesia. (2015). Peraturan Pemerintah Nomor 13 Tahun 2015 tentang Perubahan Kedua PP Nomor 19 Tahun 2005 tentang Standar Nasional Pendidikan. Berita Negara Republik Indonesia Tahun 2016. Jakarta.

Republik Indonesia. (2016). Peraturan Menteri Pendidikan dan Kebudayaan No. 22 Tahun 2016 tentang Standar Proses Pendidikan Dasar dan Menengah. Berita Negara Republik Indonesia Tahun 2016. Jakarta.

Republik Indonesia. (2016). Surat Keputusan Direktur Jederal Pendidikan Dasar dan Menengah Kementerian Pendidikan dan Kebudayaan Nomor 4678/D/Kep/MK/2016 tentang Spektrum Pendidikan Menengah Kejuruan. Berita Negara Republik Indonesia Tahun 2016. Jakarta. 